\title{
Tissue Inhibitor of Metalloproteinase-3 Ameliorates Total Sublethal Hepatic Ischemia/Reperfusion Injury in a Rat Model
}

\author{
Maureen Shuh', O. Rama Swamy', Christopher P. Zetzmann'1, George E. Loss ${ }^{2}$, Humberto Bohorquez ${ }^{2}$ and Ari J. Cohen ${ }^{1,2 *}$
}

${ }^{1}$ Laboratory of Transplant Research, Institute of Translational Research, Ochsner Health System, 1514 Jefferson Highway, New Orleans, LA 70121, USA

${ }^{2}$ Multi-Organ Transplant Center, 1514 Jefferson Highway, New Orleans, LA 70121, USA

\begin{abstract}
Orthotopic liver transplantation is the only treatment for end stage liver disease. Recipients outweigh the number of available healthy donor livers, and options for increasing the donor pool have included the use of marginal livers. Transplantation of marginal livers is a known risk factor for the development of primary non-function post-transplant. Although the precise cause of primary non-function is not known, ischemia/reperfusion $(I / R)$ injury has been strongly implicated, and tumor necrosis factor- $\alpha$ (TNF- $\alpha$ ) plays a critical role. We utilized a rat I/R model to determine whether treatment with tissue inhibitor of metalloproteinase-3 (TIMP-3) after total sublethal I/R injury improves liver health by preventing the release of active TNF- $\alpha$. Rats were pre-treated with either TIMP-3 or saline and underwent total warm hepatic ischemia followed by $6,24,48$ hours or 7 days reperfusion. All rats survived treatment and I/R injury. Serum samples were assayed for TNF- $\alpha$, interleukin-6 (IL-6), and alanine aminotransferase (ALT). Histology and RT-PCR for TNF- $\alpha$ and TNF- $\alpha$-converting enzyme [TACE or a disintegrin and metalloproteinase-17 (ADAM-17)] were performed on liver tissues. TIMP-3 treatment resulted in decreased TNF- $\alpha$ and IL-6 levels, and the inhibition occurred at a posttranscriptional level as mRNA expression of TNF- $\alpha$ and TACE/ADAM-17 was not affected. ALT levels reached basal levels in TIMP-3-treated rats more quickly than untreated rats, and livers of treated rats showed mild edema while livers of untreated rats exhibited hepatic collapse, necrosis, and hemorrhage. Our results indicate that TIMP-3 treatment protects the liver from total sublethal I/R injury through a TNF- $\alpha$-specific pathway.
\end{abstract}

Keywords: Liver; Transplantation; Tumor necrosis factor- $\alpha$; Tumor necrosis factor- $\alpha$ converting enzyme

\section{Introduction}

Orthotopic liver transplantation (OLT) is the treatment for end stage liver disease with 1- year and 5-year national patient survival rates of $89 \%$ and $80 \%$, respectively [1]. The number of potential recipients on the national waiting list far surpasses the number of healthy organs available per year for transplantation. The options for increasing the donor pool have included live donors, split livers, and marginal livers. Examples of marginal liver donors are livers from older donors, donors with significant macrosteatosis and donors with anticipated long cold ischemia times [2]. Transplantation of marginal livers is a known risk factor for the development of primary non-function after liver transplantation [3]. Primary non-function is a common cause for retransplantation and death early after OLT. Optimization of marginal liver grafts would expand their utilization without increasing the perioperative morbidity and mortality. Although the precise cause of primary non-function is not known, ischemia/reperfusion (I/R) injury has been strongly implicated $[4,5]$.

Hepatic I/R injury is a multifactorial event involving immunological responses such as cytokine and chemokine cascades, the complement system, and inflammation as well as other physiological pathways [6,7]. The cytokine tumor necrosis factor- $\alpha$ (TNF- $\alpha$ ) plays a critical role in both the physiologic defensive response to and the pathogenesis of $\mathrm{I} / \mathrm{R}$ injury in liver tissue [8-10]. TNF- $\alpha$, a potent mediator of inflammation, is a soluble cytokine primarily produced by activated monocytes, macrophages, and T-lymphocytes. In studies of liver transplantation, TNF- $\alpha$ is implicated in both the physiologic defensive response to and the pathogenesis of $\mathrm{I} / \mathrm{R}$ injury in liver tissue [11]. During ischemia, TNF- $\alpha$ levels peak during the early phase at 30 minutes to 2 hours after reperfusion due to increased production of reactive oxygen species [12]. The subsequent infiltration of innate immune cells to the liver results in additional TNF- $\alpha$ production, 6-48 hours after reperfusion. Data from experimental models of I/R injury in which TNF- $\alpha$ is blocked or decreased suggest a potential clinical benefit [13-17].
TNF- $\alpha$, a 185 amino acid (aa), 17 kiloDalton $(\mathrm{kDa})$, glycosylated protein, is synthesized as the precursor protein proTNF- $\alpha$ (212 aa, $26 \mathrm{kDa}$ ). ProTNF- $\alpha$ is transported to the membrane, and in response to stimulus, the extracellular domain is cleaved by the sheddase TNF- $\alpha$-converting enzyme (TACE), also known as a disintegrin and metalloproteinase-17 (ADAM-17), releasing the soluble and active form of TNF- $\alpha$. Active TNF- $\alpha$ binds to two receptors, TNF- $\alpha$ receptor 1 (TNFR1/p55/CD120a) and TNF-a receptor 2 (TNRF2/p75/CD120b). TNFR1 is expressed on almost all human cells, and the TNF- $\alpha-$ TNFR1 complex activates apoptosis as well as cell proliferation. TNFR2 is expressed primarily on immune cells, and unlike TNFR1, two ligands, TNF- $\alpha$ and TNF- $\beta$, bind TNFR2, resulting in transcriptional activation but not apoptosis. Thus, the interaction between TNF- $\alpha$ and TNFR1 affects a number of tissues due to TNFR1's broad expression pattern and pleiotropic activation.

The regulation of TNF- $\alpha$ is critical in controlling inflammation and is mediated in part by TACE/ADAM-17. TACE/ADAM-17 is an 824 aa, $93 \mathrm{kDa}$ protein which is a member of the disintgrin and metalloproteinase domain (ADAM) family [18]. TACE/ADAM-17 not only cleaves proTNF- $\alpha$ but also releases or sheds other ligands, including TNFR1, TNFR2, the interleukin-6 receptor (IL-6R), members of the membrane-bound epidermal growth factor (EGF) family, the Notch receptor, fractalkine/CX3CL1, L-selectin, and transforming growth

\footnotetext{
*Corresponding author: Ari J. Cohen, Laboratory of Transplant Research, Institute of Translational Research, Ochsner Health System, 1514 Jefferson Highway, New Orleans, LA 70121, USA, Tel: 504-842-3925; Fax: 504-842-5746 E-mail: acohen@ochsner.org
}

Received March 28, 2012; Accepted May 16, 2012; Published May 21, 2012

Citation: Shuh M, Swamy OR, Zetzmann CP, Loss GE, Bohorquez H, et al (2012) Tissue Inhibitor of Metalloproteinase-3 Ameliorates Total Sublethal Hepatic Ischemia/Reperfusion Injury in a Rat Model. J Transplant Technol Res S3:003. doi:10.4172/2161-0991.S3-003

Copyright: $\odot 2012$ Shuh M, et al. This is an open-access article distributed under the terms of the Creative Commons Attribution License, which permits unrestricted use, distribution, and reproduction in any medium, provided the original author and source are credited. 
Citation: Shuh M, Swamy OR, Zetzmann CP, Loss GE, Bohorquez H, et al. (2012) Tissue Inhibitor of Metalloproteinase-3 Ameliorates Total Sublethal Hepatic Ischemia/Reperfusion Injury in a Rat Model. J Transplant Technol Res S3:003. doi:10.4172/2161-0991.S3-003

factor- $\alpha(\mathrm{TGF}-\alpha)[19]$. TACE/ADAM-17 is, in turn, regulated by another endogenous protein, tissue inhibitor of metalloproteinases-3 (TIMP-3), a competitive inhibitor of TACE/ADAM-17 [20,21].

Efforts to regulate inflammation through TNF- $\alpha$ in $\mathrm{I} / \mathrm{R}$ injury during transplantation have focused primarily on pre-treatment and continuous treatment of the recipient or the donor with immunosuppressive drugs such as tacrolimus (FK-506), sirolimus (rapamycin), cyclosporine A (CsA), and corticosteroids [22-28]. However, immunosuppression prior to $\mathrm{I} / \mathrm{R}$ injury may not reduce tissue damage, and furthermore, may inhibit tissue regeneration and repair $[29,30]$. Direct and limited targeting of specific inflammatory pathways may alleviate I/R injury while retaining the physiological repair mechanisms. We previously reported that TACE/ADAM-17 is constitutively expressed in rat livers and up-regulated after partial hepatic I/R injury, and TIMP-3 had a protective effect on I/R injured livers [17]. We were interested in expanding our studies to induce I/R injury in a clinically applicable model. In this study, we examined the effect of inhibiting TACE/ADAM-17 with TIMP-3 in rats undergoing total sublethal hepatic ischemia.

Our data indicate that TIMP-3 protects the rat liver from injury during sublethal hepatic ischemia and reperfusion. Our studies suggest that a targeted approach to inhibit TNF- $\alpha$ in donor may protect the livers from extensive $\mathrm{I} / \mathrm{R}$ damage prior to removal, and thus, result in a decreased likelihood of the explanted liver to fail, leading to either death or re-transplant for the recipient.

\section{Material and Methods}

\section{Animals}

Male Wistar rats weighing 150-170 g (Harlan Laboratories, Indianapolis, IN) were assigned by computer-generated randomized list to treatment $(N=16)$ or control $(N=16)$ animal designation. The study was approved by the Institutional Animal Care and Use Committee (IACUC) at Ochsner Clinic Foundation. The animals were housed at the animal facility of Ochsner Clinic Foundation in accordance with the guidelines of the National Institutes of Health for the use of experimental animals. Surgeries and lab analysis were done on site. Syringes for the treatments were filled by a third party and labeled with sequential numbers.

\section{TIMP-3}

Recombinant human TIMP-3, expressed in mouse NSO cells, was purchased from Sigma-Aldrich (St. Louis). The purified protein has an apparent molecular weight of approximately $30 \mathrm{kDa}$ due to glycosylation. The lyophilized protein is resuspended in sterile distilled water at a stock concentration of $0.2 \mu \mathrm{g} / \mathrm{ml}$. The reconstituted TIMP3 was used to treat animals at a concentration of $1000 \mathrm{ng}$ per $1 \mathrm{~kg}$ of bodyweight.

\section{Injury model}

All animals were anaesthetized with $2 \%$ isoflurane (Vedco, Inc., St. Joseph, MO), and each group of 16 rats was treated prior to injury induction with either saline $(0.9 \% \mathrm{NaCl}$ solution; sham treatment) or TIMP-3. Treatment was administered as a bolus injection intraperitoneally one hour before injury. After treatment, the animals were again anaesthetized with $2 \%$ isoflurane and underwent laparotomy, exposing the hepatic vasculature. The sublethal ischemic injury model consisted of temporarily clamping (Schwartz micro serrefines, Fine Science Tools, Foster City, CA) the bile duct, hepatic vein and hepatic artery for 30 minutes of total warm hepatic ischemia.
The group was divided into 4 subgroups of which the livers were allowed to reperfuse for 6,24 , or 48 hours or 7 days. The 16 animals from the control group were subjected to anaesthesia, laparotomy, clamp injury and reperfusion identical to the TIMP-3-treated group. Blood, liver tissue, and spleen tissue were collected before the animals were humanely euthanized.

\section{Serum protein assays}

The Infinity ${ }^{\mathrm{TM}}$ alanine aminotransferase (ALT) liquid stable reagent (Thermoelectron Company, Louisville, CO) was used to measure serum ALT levels according to the manufacturer's protocol. Briefly, 30 $\mu \mathrm{l}$ of sample or standard was mixed with pre-warmed (5 minutes at $\left.37^{\circ} \mathrm{C}\right) 300 \mu \mathrm{l}$ of ALT reagent in a 96-well flat-bottom microplate. The plate was incubated at $37^{\circ} \mathrm{C}$ for 30 seconds, and the absorbance was measured at $340 \mathrm{~nm}$ in a Model 680XR microplate reader (Bio-Rad). At 60 minutes after the first measurement, a second absorbance at 340 $\mathrm{nm}$ was measured. The activity of ALT was calculated by the following equation: Activity $(\mathrm{U} / \mathrm{L})=\left(\Delta \mathrm{A}_{340 \mathrm{~mm}} / \mathrm{min}\right)$ (Factor) where Factor $=$ [(Total reaction volume $(\mathrm{mL})(1000)] /[(6.3)$ (Sample volume in $\mathrm{mL}$ ) (cuvette pathlength in $\mathrm{cm}$ ). The protein levels of IL-6 and TNF- $\alpha$ were measured by ELISA with the Quantikine ${ }^{\circledR}$ Rat IL-6 Immunoassay and the Quantikine ${ }^{\circledR}$ Rat TNF- $\alpha$ Immunoassay kits (R\&D Systems, Minneapolis, MN), respectively, according to the manufacturer's protocol. Serum samples were allowed to clot for 30 minutes at room temperature and centrifuged at $1000 \mathrm{x} g$ prior to analysis. The data are presented as means \pm standard deviation, and comparisons between the groups were made by use of analysis of variance. A $P$ value less than 0.05 was considered statistically significant.

\section{RNA extraction and reverse transcription-polymerase chain reaction (RT-PCR)}

Total RNA from liver tissues stabilized in RNA later solution (Qiagen, Valencia, CA) was extracted using the RNeasy Mini Kit (Qiagen). DNA contamination was eliminated by incubating the RNA with RNase-Free DNase (Promega, Madison, WI) for 10 minutes at room temperature. The RNA preparation was quantified by measuring A260 nm with a spectrophotometer. Reverse transcription of freshly prepared $1 \mu \mathrm{g}$ RNA was performed in a total volume of $20 \mu \mathrm{l}$ containing $10 \mathrm{mM}$ dithiothreitol (DTT), $50 \mathrm{mM}$ Tris- $\mathrm{HCl}, 75 \mathrm{mM} \mathrm{KCl}, 3 \mathrm{mM}$ $\mathrm{MgCl}_{2}, 0.5 \mu \mathrm{M}$ deoxynucleotide triphosphates (dNTPs), $200 \mathrm{ng}$ random primers, and 10 units of Moloney murine leukemia virus reverse transcriptase (Invitrogen, Carlsbad, CA). The reaction mixture was incubated at $42^{\circ} \mathrm{C}$ for $1 \mathrm{hr}$ for reverse transcription, followed by $95^{\circ} \mathrm{C}$ for $15 \mathrm{~min}$ to inactivate the reverse transcriptase. One microliter of the cDNA was used for PCR amplification in a total volume of $50 \mu \mathrm{L}$ with $1 \mathrm{X}$ reaction mixture $[10 \mathrm{mM}$ Tris- $\mathrm{HCl}, 50 \mathrm{mM} \mathrm{KCl}, 1 \%$ Triton $\mathrm{X}-100$, $2.5 \mathrm{mM} \mathrm{MgCl}, 0.2 \mu \mathrm{M}$ dNTPs, $0.4 \mu \mathrm{M}$ specific primers, and two units of Taq DNA polymerase (Promega, Madison, WI)]. Twenty-five cycles of PCR amplification were performed, each cycle with denaturation at $94^{\circ} \mathrm{C}$ for $45 \mathrm{sec}$, annealing at $60^{\circ} \mathrm{C}$ for $30 \mathrm{sec}$, and elongation at $72^{\circ} \mathrm{C}$ for $45 \mathrm{sec}$. The primer sequences were as follows: rat TACE/ADAM-17 forward primer 5' ACG TAA TTG AGC GGT TTT GG-3' (nt 21812200), reverse primer 5' GAC TGG GTG GTC TGT GAG GT-3' (nt 2650-2631), GenBank accession AJ012603; rat TNF- $\alpha$ forward primer 5'-TGA GCA CAG AAA GCA TGA TC-3' (nt 2-21), reverse primer 5'-CAT CTG CTG GTA CCA CCA GTT-3' (nt 397-378), GenBank accession X66539; and rat glyceraldehyde 3-phosphate dehydrogenase, forward primer 5' TCC CTC AAG ATT GTC AGC AA-3' (nt 497516), reverse primer 5' AGA TCC ACA ACG GAT ACA TT-3' (nt 804785), and GenBank accession BC059110. All primers were synthesized and purified by Integrated DNA Technologies (Coralville, IA). The 
Citation: Shuh M, Swamy OR, Zetzmann CP, Loss GE, Bohorquez H, et al. (2012) Tissue Inhibitor of Metalloproteinase-3 Ameliorates Total Sublethal Hepatic Ischemia/Reperfusion Injury in a Rat Model. J Transplant Technol Res S3:003. doi:10.4172/2161-0991.S3-003

amplified PCR products were analyzed in a $1.5 \%$ agarose gel.

\section{Histology}

Liver tissues from both treated and untreated animals were harvested and immediately fixed in $10 \%$ formalin. All samples were sent to pathology for routine processing, including embedding, sectioning, and hemolysin-eosin staining. The stained sections were blinded and analyzed by a pathologist.

\section{Results}

TIMP-3 inhibition of TACE/ADAM-17 prevents cleavage of proTNF- $\alpha$, presumably decreasing the availability of active, soluble TNF- $\alpha$. To determine whether TIMP-3 treatment reduces the TNF- $\alpha$ level in livers undergoing total sub lethal hepatic ischemia in vivo, we utilized a rat I/R injury model. Analysis of serum samples showed that TNF- $\alpha$ levels for control animals were $60 \mathrm{pg} / \mathrm{ml}$ at 6 hours of reperfusion and peaked at $48 \mathrm{hrs}$ while TIMP-3-treated animals had at least 2-fold less serum TNF- $\alpha$ when comparing all time points of reperfusion duration (Figure 1). Even more striking, at 48 hours of reperfusion, TNF- $\alpha$ levels for TIMP-3-treated were 10-fold lower than untreated animals, suggesting that pre-treatment of animals with TIMP-3 prior to I/R injury resulted in decreased production of TNF- $\alpha$ in the serum and that TIMP- 3 treatment maintained a steady state TNF- $\alpha$ level in the serum, regardless of reperfusion duration.

Since TIMP-3 is a competitive inhibitor of TACE/ADAM-17, we expected that the lower levels of TNF- $\alpha$ in TIMP-3-treated animal were not due to transcriptional regulation. To confirm that TIMP-3 treatment did not affect gene expression, we performed RT-PCR to assess both TNF- $\alpha$ and TACE/ADAM-17 mRNAs. The expression of both genes in TIMP-3-treated animals (Figure 2, odd-numbered lanes) was the same as untreated animals (Figure 2, even numbered lanes), and the levels were the same for all reperfusion time points. Thus, the decreased serum levels in TIMP-3-treated rats prior to I/R induction was not due to regulation of TNF- $\alpha$ and TACE/ADAM-17 gene expression.

Since TNF- $\alpha$ signaling result in up-regulation of downstream proinflammatory cytokines, we next examined the effect of TIMP- 3 on the levels of IL- 6 which is expressed and secreted due to TNF- $\alpha$ induction. In saline-treated, negative control animals, serum IL- 6 levels peaked to almost $150 \mathrm{pg} / \mathrm{ml}$ after 6 and 24 hours of reperfusion before decreasing to $93 \mathrm{pg} / \mathrm{ml}$ at 48 hours reperfusion and $65 \mathrm{pg} / \mathrm{ml}$ after 7 days of reperfusion (Figure 3). In contrast, the levels of serum IL-6 in TIMP-3treated rats stayed almost the same at all reperfusion time points with a small peak at 24 hours: $28 \mathrm{pg} / \mathrm{ml}$ (6 hrs), $49 \mathrm{pg} / \mathrm{ml}$ ( $24 \mathrm{hrs}), 28 \mathrm{pg} / \mathrm{ml}$ ( $48 \mathrm{hrs}$ ), and $30 \mathrm{pg} / \mathrm{ml}$ (7 days). The serum IL-6 levels mimic the TNF- $\alpha$ levels (compare Figure 1 and 3, TIMP-3), exhibiting steady state levels in pre-treated but not in untreated rats.

In our total sublethal I/R injury model here, TIMP-3-treatment of rats had reduced serum ALT levels by 2 - to 3 -fold after all time points of reperfusion as compared to the untreated control animals (Figure 4). While ALT levels was significantly different in untreated compared to TIMP-3-treated rats, histological examination of the liver tissue indicated a more gradual and subtle change until day 7 of reperfusion in which histological changes were much more pronounced. After ischemia induction and 6 hours of reperfusion, the TIMP-3-treated livers appear similar to untreated livers with little or no damage seen (compare Figure 5A and 5E). Untreated rats who underwent total sub lethal ischemia followed by 24 hours of reperfusion exhibited slight signs of liver architecture collapse as shown by the infiltration of red blood cells into the plates of hepatocytes (arrow, Figure 5B; compare with Figure 5F). Strangely, we did not see much difference in liver histology between untreated and treated livers after 48 hours reperfusion (compare Figure 5C and 5G). However, after 7 days of reperfusion, the untreated liver exhibited dramatic hemorrhaging (labeled "H," Figure 5D). The increasing sinusoidal space (arrows, Figure 5D) is most likely due to lysis of the sinusoidal lining cells, leading to hemorrhaging. The TIMP-3-treated liver exhibited almost normal liver architecture after 7 days of reperfusion with slight hemorrhaging seen in the sinusoidal space ("Si" in Figure 5H).

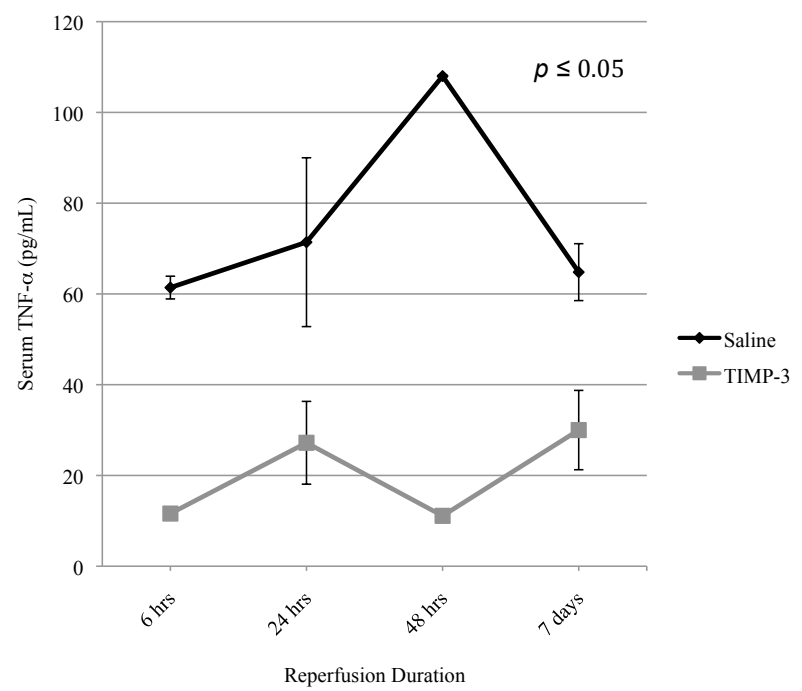

Figure 1: TNF- $\alpha$ serum levels of TIMP-3-treated rats compared to salinetreated rats exposed to liver $\mathrm{I} / \mathrm{R}$ injury. Rat blood samples were allowed to clot to isolate serum. Serum samples were quantified for TNF- $\alpha$ by ELISA as per manufacturer's protocol. TNF- $\alpha$ levels on the $Y$-axis $(\mathrm{pg} / \mathrm{ml})$ are shown for TIMP-3-treated rats and saline-treated rats prior to ischemia/reperfusion injury. The X-axis indicates the length of reperfusion time for TIMP-3-treated and saline-treated rats.

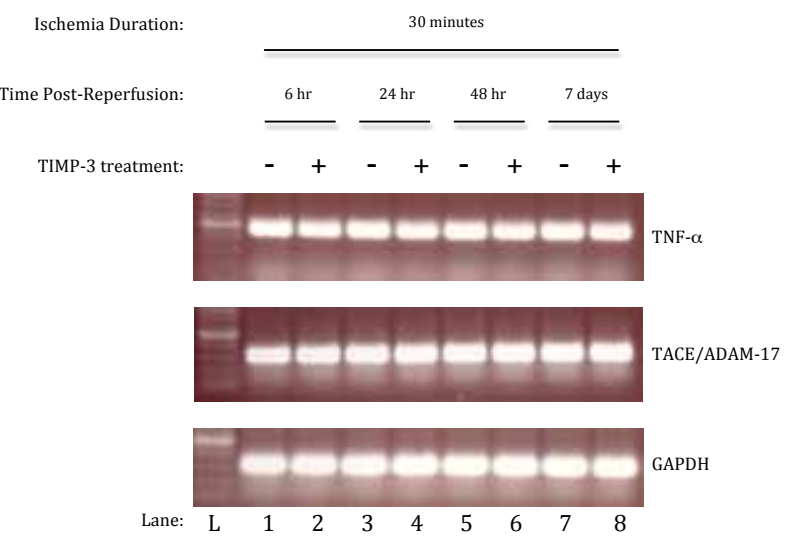

Figure 2: Gene expression of TNF- $\alpha$, TACE/ADAM-17, and GAPDH in liver tissue of TIMP-3-treated rats compared to saline-treated rats exposed to I/R injury. Total mRNA extracted from rat liver tissues were analyzed by RTPCR for TNF- $\alpha$, TACE/ADAM-17, and GAPDH mRNA. TIMP-3-treatment and saline treatment are denoted by + and -, respectively. All rats underwent 30 minute ischemia, followed by varying reperfusion duration ( 6 hrs, 24 hrs, 48 hrs or 7 days). The PCR products were analyzed by agarose gel eletrophoresis, stained with ethidium bromide. 


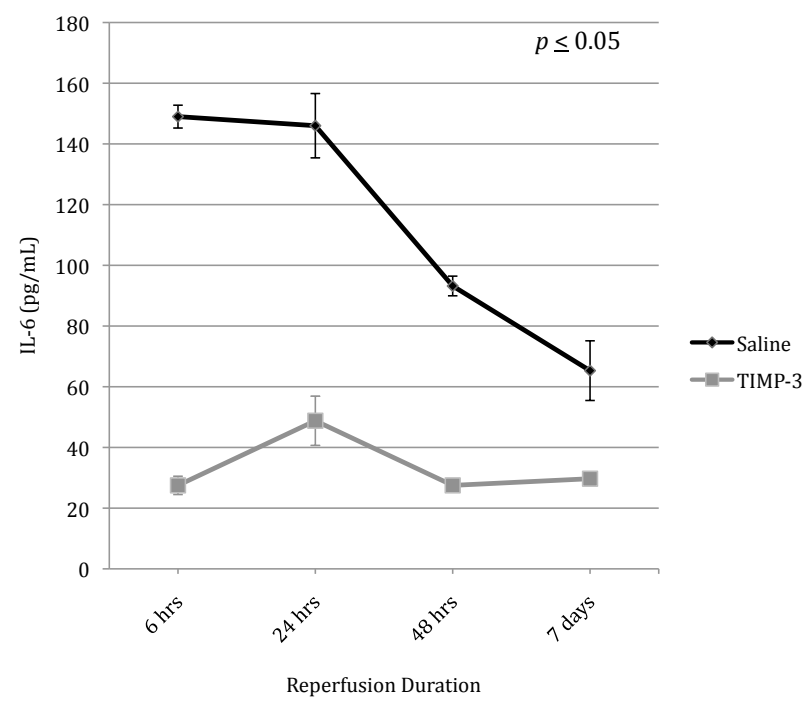

Figure 3: IL-6 serum levels of TIMP-3-treated rats compared to saline-treated rats exposed to liver I/R injury. Serum samples were quantified for IL-6 by ELISA as per manufacturer's protocol. IL-6 levels on the $Y$-axis $(\mathrm{pg} / \mathrm{ml})$ are shown for TIMP-3-treated rats and saline-treated rats prior to ischemia/ reperfusion injury. The $\mathrm{X}$-axis indicates the length of reperfusion time for TIMP-3-treated and saline-treated rats

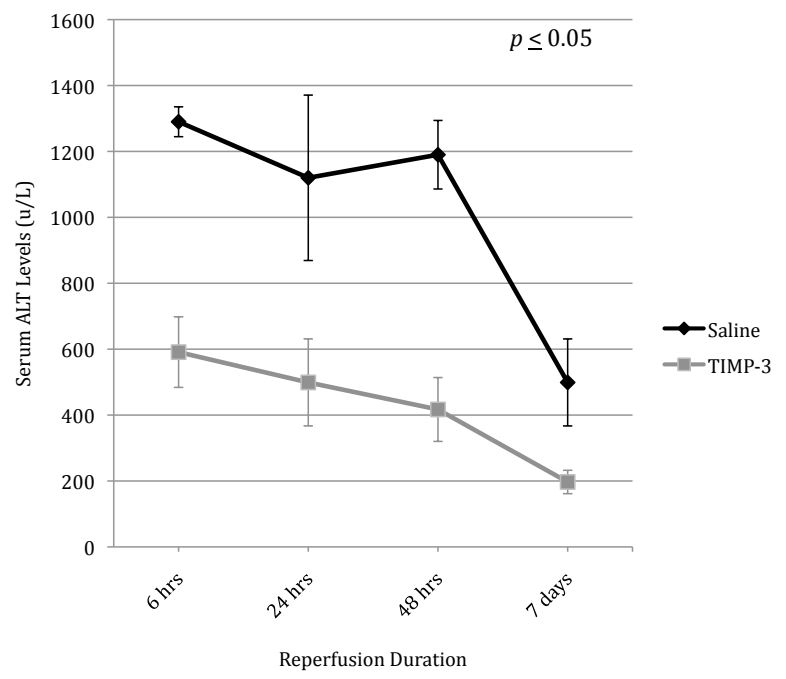

Figure 4: $L$-alanine 2-oxoglutarate aminotransferase (ALT) serum levels of TIMP-3-treated rats compared to saline-treated rats exposed to liver $I / R$ injury. A reagent for quantification of ALT was used to determine ALT serum levels as per manufacturer's instructions. ALT levels on the Y-axis (units/Liter) are shown for TIMP-3-treated rats and saline-treated rats prior to ischemia/reperfusion injury. The X-axis indicates the length of reperfusion time for TIMP-3-treated and saline-treated rats.

\section{Discussion}

TNF- $\alpha$ is a potent mediator of $\mathrm{I} / \mathrm{R}$ injury [31], and the inhibition of TNFC $\alpha$ appears to protect livers from damage [12]. TIMP-3 is a highly specific inhibitor of TACE/ADAM-17 and has been shown to regulate inflammation [32]. We hypothesized that $\mathrm{I} / \mathrm{R}$ injury induces an inflammatory cascade and that TIMP-3 treatment of rats undergoing $\mathrm{I} / \mathrm{R}$ injury to the liver would result in decreased levels of
TNF- $a$ with a concomitant improvement in liver health as compared to untreated animals. In the present study, we exposed rats to 30 minutes of ischemia, followed by $6,24,48$ hours or 7 days of reperfusion. The rats were either pre-treated with recombinant TIMP-3 or saline prior to induction of I/R injury. We show here that TIMP-3-treated rats exhibited decreased serum levels of TNF- $\alpha$ when subjected to total sub lethal hepatic I/R injury. The treated rats also had decreased IL-6, liver ALT and tissue damage. Our data suggest that in our rat model, TIMP-3 pre-treatment modulates the amount of active TNF- $\alpha$ in the serum up to 7 days, presumably by inhibiting TACE/ADAM-17 and preventing the release of soluble TNF- $\alpha$.

We previously reported that TIMP-3 treatment of rats undergoing partial warm ischemia decreased the levels of serum TNF- $\alpha$ and protected the liver from tissue damage [17]. With the partial warm ischemia model, two other potential factors may play a role in regulating TACE/ADAM-17. First, allowing flow from the superior mesenteric vein into the right portal vein may have minimized bowel congestion and altered the circulation of cytokines from the bowel mucosa. We now induced ischemia by clamping the bile duct, portal vein, and the hepatic artery for 30 minute which renders $70 \%$ of the liver volume ischemic followed by $6,24,48 \mathrm{hr}$ or 7 day reperfusion and have found no difference in our previous results and those reported here [33,34] Secondly, the nonischemic right lobe may contain metabolized TNF- $\alpha$, which may be bound to TACE/ADAM-17 prior to TIMP-3 treatment. Our current method of clamping of the bile duct, portal vein, and
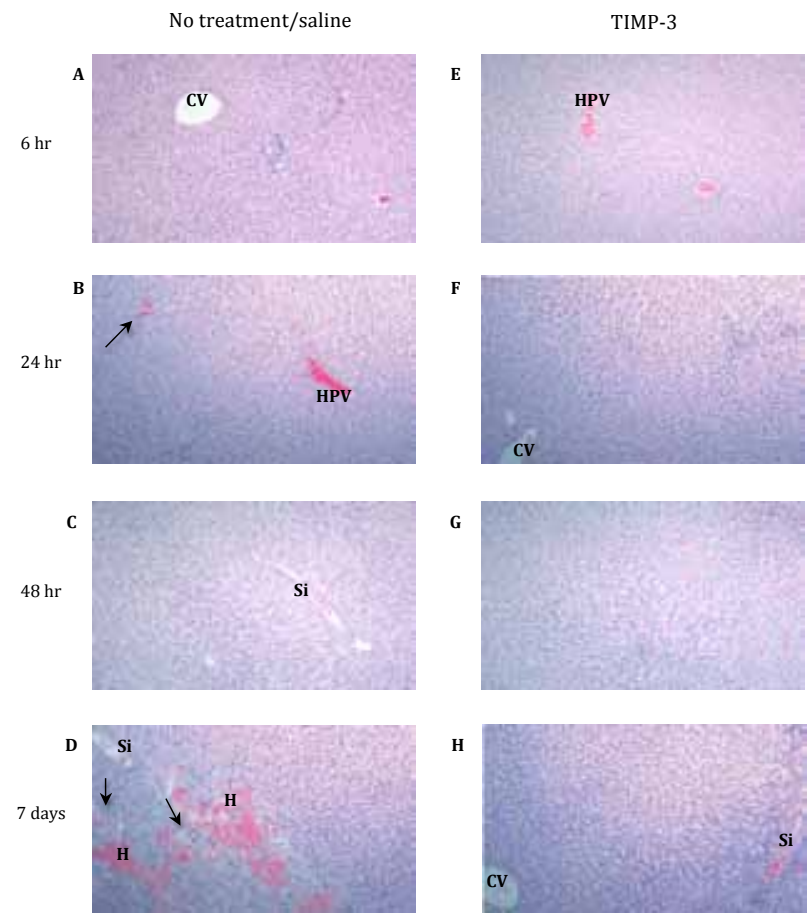

Figure 5: Histology of rat liver sections. Liver sections were fixed in formalin, embedded in paraffin, sectioned, and stained with hemolysin-eosin which are shown. The slides are labeled as follows for treatment: A-D, saline-treated rats; E-H, TIMP-3 treated rats. After treatment, all rats underwent 30 minutes of ischemia with various reperfusion duration: $A$ and $E, 6$ hours reperfusion; $B$ and F, 24 hours reperfusion; $C$ and $G, 48$ hours reperfusion; $D$ and $H, 7$ days reperfusion. Abbreviations: $\mathrm{CV}$, central vein; HPV, hepatic portal vein; $\mathrm{Si}$, sinusoids; and $\mathrm{H}$, hemorrhaging. The arrow in panel $\mathrm{B}$ points to aberrant red blood cells in the plates of hepatocytes, and arrows in panel $D$ point to examples of increasing sinusoidal space occurring in 
hepatic artery to induce ischemia in the entire liver eliminates the possibility of soluble TNF- $\alpha$ in the right lobe.

We have shown a dose-dependent effect of TIMP-3-treated rats prior to inducing partial warm I/R injury [17]. While a dose of $100 \mathrm{ng} /$ $\mathrm{kg}$ bodyweight also significantly decreased TNF- $\alpha$ and ALT levels by almost two-fold compared to the untreated rats, we chose the 1,000 ng/ $\mathrm{kg}$ bodyweight dose due to the 4 - to 5 -fold decrease in serum TNF- $\alpha$ after 6 hours of reperfusion. More importantly, the ALT levels of the TIMP-3-treated rats at the $1,000 \mathrm{ng} / \mathrm{kg}$ dose exhibited low levels of ALT similar to normal non-ischemic animals. Thus, we used the 1,000 $\mathrm{ng} / \mathrm{kg}$ TIMP-3 dose for the studies reported here. While we have been interested in examining TIMP-3 peptides as inhibitors rather than the full-length protein, peptide-length TIMP-3 appears to be ineffective at binding the active site of TACE/ADAM-17 as the endogenous TIMP-3 does. The N-terminal domain of TIMP-3 is effective; however, three disulfide bonds in the N-terminus domain result in folding TIMP-3 for specific contacts with TACE/ADAM-17 which cannot be mimicked at the peptide level $[35,36]$. Although present in the literature, synthetic TIMP-3 peptides that bind allosteric sites have not been tested for biological activity against TACE/ADAM-17 in vivo and would be interesting to test in our rat I/R model.

While several anti-TNF- $\alpha$ antibodies are approved for clinical use against chronic inflammatory diseases, particular for rheumatoid arthritis, few reports have demonstrated effective use of TNF- $\alpha$ antibody in liver I/R injury [37-39]. Ben-Ari et al. [15], previously demonstrated an increase in TNF- $\alpha$ in the effluent of isolated rat livers (blood free environment) after I/R injury induction, and monoclonal TNF- $\alpha$ antibody pre-treatment of the ex vivo liver attenuated liver injury. In vivo, use of etanercept was not effective at attenuating $\mathrm{I} / \mathrm{R}$ injury in a rat retinal ischemia model ( 30 or 45 minute ischemia followed by reperfusion up to 48 hours) [40]. While antibody treatment decreases TNF- $\alpha$ level in a controlled I/R ex vivo model, the levels of TNF- $\alpha$ would most likely be present at a high level in a human donor liver as we have demonstrated in a small pilot study of human donors [41]. Antibody treatment, therefore, would be too late in preventing TNF- $\alpha$ from binding to TNF- $\alpha$ receptors. Hernandez-Alejandro et al. [42], recently showed that targeting the TNF- $\alpha$ gene with shRNA resulted in a $40 \%$ decrease in ALT and AST levels with normal liver histology in an I/R mouse model. The mice were treated with TNF- $\alpha$ shRNA two days prior to ischemia for 60 minutes and 6 hours of reperfusion. They did not measure serum TNF- $\alpha$ levels although the TNF- $\alpha$ mRNA was decreased by half compared to untreated control mice. TIMP-3 treatment in our rat model resulted in an almost 60\% decrease in ALT levels with a concurrent 6-fold decrease in TNF- $\alpha$ protein.

The analysis of TIMP-3 metabolic turnover is an important issue, one that is the sole subject of investigation, particularly since MMPs are increasingly becoming an attractive therapeutic target for diseases, including cancer. There are not many published studies on TIMP turnover rates, most likely due to the need to construct a tagged protein to differentiate between the endogenous and the exogenous protein, to produce enough quantities of protein for in vivo application, and to perform the in vivo pharmacokinetics study. Langton et al. [43], transfected a TIMP-3-His plasmid construct into Retinal Pigment Epithelial (RPE) cells and measured the turnover rate of the tagged protein. They found that $80 \%$ of the TIMP-3-His protein was gone from the extracellular matrix and less than $1 \%$ was present after day 4 . Their calculations indicate that the half-life of exogenous TIMP-3-His is approximately 9.5 hours in a cell line. Nakajima et al. [44], injected a lentviral TIMP-3 construct into the tail vein of mice to determine the effect of exogenous TIMP-3 treatment on the regulation of hematopoietic stem cells in vivo. They showed that TIMP-3 expression is induced in the mice up to and including day 9. The authors indicate in their discussion that TIMP-3 has a short half-life in vivo but do not include a reference, and they did not determine half-life of exogenous TIMP-3 in their experiments. With another recombinant TIMP protein, Lee et al., undertook a laborintensive effort to measure the pharmcokinetics of a fusion TIMP-2 construct. The TIMP-2 was expressed as a fusion protein with human serum albumin and expressed in yeast. They tagged the TIMP-2-HAS fusion protein with Cy5.5 near infrared fluorescence. They calculated a blood half-half of 19.5 hours. The presence of the fusion protein was detected in day 2 of prostate tumors with decreasing signal by day 4 . Based on these published reports, we believe that exogenous TIMP-3 is present in during the ischemia induction in our study and during the 6 hours reperfusion, possibly longer. We suggest that the TIMP-3 effects, however, occur within this time frame and that the outcome of inhibiting TACE/ADAM-17 is not dependent on the persistence of exogenous TIMP-3 since we continue to see improved liver health at 24 hour, 48 hour, and 7 day reperfusion.

TNF- $\alpha$ is a key mediator in inflammation, and inhibitors of TNF- $\alpha$ are effective for management for various autoimmune diseases such as Crohn's disease and rheumatoid arthritis. Studies have now identified that TNF- $\alpha$ plays a critical role in I/R injury after solid organ transplantation and experimental models suggest that inhibition of TNF- $\alpha$ may prove to be beneficial in attenuating $I / R$ injury. Most treatment options to alleviate damage due to $\mathrm{I} / \mathrm{R}$ injury is to focus on the recipient. We suggest that TIMP-3 pre-treatment of the donor, particularly cadaveric donors, prior to organ removal may improve donor liver health, and thereby, improve the outcome of the recipient following liver transplantation.

\section{Acknowledgements}

The research was funded by Ochsner Clinic Foundation, New Orleans, LA M.S. thanks Dr. E. Leticia Beard (Loyola University New Orleans) for helpful discussions

\section{References}

1. SBIR Scientific Registry of Transplant Recipients.

2. Busuttil RW, Tanaka K (2003) The utility of marginal donors in liver transplantation. Liver Transpl 9: 651-663.

3. de Graaf EL, Kench J, Dilworth P, Shackel NA, Strasser SI, et al. (2012) Grade of deceased donor liver macrovesicular steatosis impacts graft and recipient outcomes more than Donor Risk Index. J Gastroenterol Hepatol 27: 540-546.

4. Kupiec-Weglinski JW, Busuttil RW (2005) Ischemia and reperfusion injury in liver transplantation. Transplant Proc 37: 1653-1656.

5. ljtsma AJ, van der Hilst CS, de Boer MT, de Jong KP, Peeters PM, et al. (2009) The clinical relevance of the anhepatic phase during liver transplantation. Liver Transpl 15: 1050-1055.

6. Abu-Amara M, Yang SY, Tapuria N, Fuller B, Davidson B, et al. (2010) Liver ischemia/reperfusion injury: processes in inflammatory networks--a review. Liver Transpl 16: 1016-1032.

7. Zhai Y, Busuttil RW, Kupiec-Weglinski JW (2011) Liver ischemia and reperfusion injury: new insights into mechanisms of innate-adaptive immunemediated tissue inflammation. Am J Transplant 11: 1563-1569.

8. Teoh N, Leclercq I, Pena AD, Farrell G (2003) Low-dose TNF-alpha protects against hepatic ischemia-reperfusion injury in mice: implications for preconditioning. Hepatology 37: 118-128.

9. Teoh N, Field J, Sutton J, Farrell G (2004) Dual role of tumor necrosis factoralpha in hepatic ischemia-reperfusion injury: studies in tumor necrosis factoralpha gene knockout mice. Hepatology 39: 412-421.

10. Schwabe RF, Brenner DA (2006) Mechanisms of Liver Injury. I. TNF-alphainduced liver injury: role of IKK, JNK, and ROS pathways. Am J Physio Gastrointest Liver Physiol 290: G583-G589. 
Citation: Shuh M, Swamy OR, Zetzmann CP, Loss GE, Bohorquez H, et al. (2012) Tissue Inhibitor of Metalloproteinase-3 Ameliorates Total Sublethal Hepatic Ischemia/Reperfusion Injury in a Rat Model. J Transplant Technol Res S3:003. doi:10.4172/2161-0991.S3-003

11. Hsu YC, Chou TY, Chen CF, Wang D, Su CL, et al. (2008) Rat liver ischemia/ reperfusion induced proinflammatory mediator and antioxidant expressions analyzed by gene chips and real-time polymerase chain reactions. Transplant Proc 40: 2156-2158.

12. Perry BC, Soltys D, Toledo AH, Toledo-Pereyra LH (2011) Tumor necrosis factor- $\alpha$ in liver ischemia/reperfusion injury. J Invest Surg 24: 178-188.

13. Colletti LM, Remick DG, Campbell DA Jr (1994) Desferal attenuates TNF release following hepatic ischemia/reperfusion. J Surg Res 57: 447-453.

14. Peng XX, Currin RT, Thurman RG, Lemasters JJ (1995) Protection by pentoxifylline against normothermic liver ischemia/reperfusion in rats. Transplantation 59: 1537-1541.

15. Ben-Ari Z, Hochhauser E, Burstein I, Papo O, Kaganovsky E, et al. (2002) Role of anti-tumor necrosis factor-alpha in ischemia/reperfusion injury in isolated rat liver in a blood-free environment. Transplantation 73: 1875-1880.

16. Yoshizumi T, Yonemitsu Y, Ikeda Y, Kaneda Y, Yanaga K, et al. (2006) Tumo necrosis factor-a antisense transfer remarkably improves hepatic graft viability. Liver Int 26: 451-456.

17. Tang ZY, Loss G, Carmody I, Cohen AJ (2006) TIMP-3 ameliorates hepatic ischemia/reperfusion injury through inhibition of tumor necrosis factor-alphaconverting enzyme activity in rats. Transplantation 82: 1518-1523.

18. Gooz M (2010) ADAM-17: the enzyme that does it all. Crit Rev Biochem Mo Biol 45: 146-169.

19. Edwards DR, Handsley MM, Pennington CJ (2008) The ADAM metalloproteinases. Mol Aspects Med 29: 258-289.

20. Amour A, Slocombe PM, Webster A, Butler M, Knight CG, et al. (1998) TNFalpha converting enzyme (TACE) is inhibited by TIMP-3. FEBS Lett 435: 39-44

21. Wisniewska M, Goettig P, Maskos K, Belouski E, Winters D, et al. (2008) Structural determinants of the ADAM inhibition by TIMP-3: crystal structure of the TACE-N-TIMP-3 complex. J Mol Biol 381: 1307-1319.

22. Sakr MF, McClain CJ, Gavaler JS, Zetti GM, Starzl TE, et al. (1993) FK 506 pre-treatment is associated with reduced levels of tumor necrosis factor and interleukin 6 following hepatic ischemia/reperfusion. J Hepatol 17: 301-307.

23. Kawano K, Kim YI, Goto S, Kai T, Shimada T, et al. (1992) FK 506 ameliorates normothermic liver ischemia in rats by suppressing production of tumor necrosis factor. Transpl Int 5: S665-S669.

24. Kawano K, Kim YI, Kai T, Ishii T, Tatsuma T, et al. (1994) Evidence that FK506 alleviates ischemia/reperfusion injury to the rat liver: in vivo demonstration for suppression of TNF-a production in response to endotoxemia. Eur Surg Res 26: 108-115.

25. Okano K, Hamamoto I, Izuishi K, Wakabayashi H, Akram HM, et al. (1994) Ameliorative effect of FK 506 on cold ischemia reperfusion injury of the rat liver. Transplant Proc 26: 2367-2369.

26. Kawano K, Bowers JL, Clouse ME (1995) Protective effect of FK 506 on hepatic injury following cold ischemic preservation and transplantation: influence on hepatic microcirculation. Transplant Proc 27: 362-363.

27. Cicora F, Lausada N, Vasquez DN, Cicora P, Zalazar G, et al. (2010) Sirolimus in kidney transplant donors and clinical and histologic improvement in recipients: rat model. Transplant Proc 42: 365-370.
28. Cicora F, Roberti J, Vasquez D, Guerrieri D, Lausada N, et al. (2012) Preconditioning donor with a combination of tacrolimus and rapamacyn to decrease ischaemia-reperfusion injury in a rat syngenic kidney transplantation model. Clin Exp Immunol 167: 169-177.

29. Liu YX, Jin LM, Zhou L, Xie HY, Jiang GP, et al. (2010) Sirolimus attenuates reduced-size liver ischemia-reperfusion injury but impairs liver regeneration in rats. Dig Dis Sci 55: 2255-2262.

30. Martinez-Palli G, Hirose R, Liu T, Xu F, Dang K, et al. (2011) Donor pre-treatmen with everolimus or cyclosporine does not reduce ischaemia-reperfusion injury in a rat kidney transplant model. Nephrol Dial Transplant 26: 1813-1820.

31. Colletti LM, Remick DG, Burtch GD, Kunkel SL, Strieter RM, et al. (1990) Role of tumor necrosis factor-alpha in the pathophysiologic alterations after hepatic ischemia/reperfusion injury in the rat. J Clin Invest 85: 1936-1943.

32. Black RA (2004) TIMP3 checks inflammation. Nat Genet 36: 934-935.

33. Cohen AJ Unpublished data.

34. Nishimura T, Yoshida Y, Watanabe F, Koseki M, Nishida T, et al. (1986) Blood level of mitochondrial aspartate aminotransferase as an indicator of the exten of ischemic necrosis of the rat liver. Hepatology 6: 701-707.

35. Lee MH, Knäuper V, Becherer JD, Murphy G (2001) Full-length and N-TIMP-3 display equal inhibitory activities toward TNF-alpha convertase. Biochem Biophys Res Commun 280: 945-950.

36. Murphy G Personal communication

37. Elliott MJ, Maini RN, Feldmann M, Kalden JR, Antoni C, et al. (1994) Randomised double-blind comparison of chimeric monoclonal antibody to tumour necrosis factor alpha (CA2) versus placebo in rheumatoid arthritis. Lancet 344: 1105-1110.

38. Elliott MJ, Maini RN, Feldmann M, Long-Fox A, Charles P, et al. (1994) Repeated therapy with monoclonal antibody to tumour necrosis factor alpha (cA2) in patients with rheumatoid arthritis. Lancet 344: 1125-1127.

39. Wallis RS (2011) Biologics and infections: lessons from tumor necrosis facto blocking agents. Infect Dis Clin North Am 25: 895-910.

40. Abcouwer SF, Lin CM, Wolpert EB, Shanmugam S, Schaefer EW, et al. (2010) Effects of ischemic preconditioning and bevacizumab on apoptosis and vascular permeability following retinal ischemia-reperfusion injury. Invest Ophthalmol Vis Sci 51: 5920-5933.

41. Zetzmann CP, Swamy OR, Loss GE Jr, Bohorquez H, Cohen AJ (2010) Improving Donor Livers by Inhibiting TNF- $\alpha$ Production. Ochsner J 10: 250255

42. Hernandez-Alejandro R, Zhang X, Croome KP, Zheng X, Parfitt J, et al. (2011) Reduction of liver ischemia reperfusion injury by silencing of TNF-a gene with shRNA. J Surg Res [Epub ahead of print]

43. Langton KP, McKie N, Smith BM, Brown NJ, Barker MD (2005) Sorsby's fundus dystrophy mutations impair turnover of TIMP-3 by retinal pigment epithelia cells. Hum Mol Genet 14: 3579-3586.

44. Nakajima H, Ito M, Smookler DS, Shibata F, Fukuchi Y, et al. (2010) TIMP-3 recruits quiescent hematopoietic stem cells into active cell cycle and expands multipotent progenitor pool. Blood 116: 4474-4482.
This article was originally published in a special issue, Ischemia - Reperfusion Injury handled by Editor(s). Dr. Manuel Maglione, Innsbruck Medica University, Austria; Dr. Pankai Saxena, University of Western Australia, Australia 